\title{
The Korean Peninsula and the Dream of the United States of America (1834-1882)
}

\section{Dereje Teshome Birru}

Department of Political Science, The Academy of Korean Studies, Democratic People's Republic Korea

*Corresponding author: Dereje Teshome Birru, Department of Political Science, The Academy of Korean Studies, Democratic People's Republic Korea, Tel: +1 202-862-5600; E-mail: dereje118@gmail.com

Received date: October 19, 2018; Accepted date: November 19, 2018; Published date: November 27, 2018

Copyright: @ 2018 Birru DT. This is an open-access article distributed under the terms of the Creative Commons Attribution License, which permits unrestricted use, distribution, and reproduction in any medium, provided the original author and source are credited.

\section{Abstract}

The word Korea came to America's vocabulary list on May 13, 1834 when Edmund Robert reported to Secretary of State that opening Japan was advantageous to trade with Korea. From this time onward U.S. of America devoted to open Korea. However, having the fact that during the early and the mid-19th Century Western intrusion into Korea was unwelcome and unwanted, opening Korea for American market was so tiresome. It took almost half of a century. The first attempt of opening Korea was on February 15, 1845, when Congressman Zadock Pratt, Chairman of U.S. House Committee on Naval Affairs, introduced a resolution for a mission to open Japan and Korea, and unfortunately, the resolution was failed to pass. However, the 1860 s increasing significance of Pacific trade spurred the American Government into action on the Far Eastern front and the United States again renewed its efforts to open Korea to America trade. It used the Sherman Incident as a pretext to sail to Korean waters. The Sherman Incident was the burning down of American schooner named General Sherman on September 5, 1866, at Taedong near present-day Pyongyang. After heard the incident, in 1871 U.S. sent Frederick F. Low, U.S. minister in China, and Rear-Admiral Rodger, commander in chief of America navy of Asiatic squadron, to Korea accompany by Five ships and more than 1200 sailors. However, the coming of these crew to the Korean waters turned the situation to worse and finally, led to the breaking out of the First Korean War which claimed the lives of more than 250 Koreans and 3 Americans, and other casualties. In spite of the continuous diplomatic failure and the bloody war, U.S. interest in Korea did not abate. In April 1878, Senator A. A. Sargent introduced a joint resolution authorizing the President to appoint a commission to negotiate a treaty with Korea with the aid of the friendly office of Japan. This resolution; however, never adopted and Japan suspected with ulterior motives. Whatever happened, U.S was still hungry of the unfulfilled dream. As a result, it used the good office of China which led to Shin Chen and Chin Hong-Chi of the Korean Royal Cabinet signed the Shufeldt Treaty of Peace, Amity, Commerce and Navigation on behalf of King Gojong on May 22, 1882.
\end{abstract}

Keywords: Korean peninsula; Hermit kingdom; Opening Korea; Sherman incident; First Korean war; Treaty of peace; Amity; Commerce; Navigation

\section{Introduction}

The Korean Peninsula is one of the geostrategic areas in Northeast Asia. Due to its strategic significance, the Peninsula was a battle of competition among superpowers which tied up the Peninsula within a vicious circle of conflicts. James I. Matray explained that geographical location was one of the reasons for the crisis in the Korean Peninsula [1]. He stated that the Korean Peninsula is the crossroads of Northeast Asia. Sharing borders to the North with China of 636 miles along the Yalu river and with Russia of 11 miles along the Tumen river; to the West is the Yellow Sea and at a distance of 119 miles China's Shantung Peninsula; and Japan's Islands of Honshu and Kyushu are about 120 miles to the east across the Sea of Japan. As a result, the Korean Peninsula always caught the eyes of its neighbor. Yu Nam Kim stated that due to its strategic location, the Korean Peninsula draw the interest of its larger neighbors for over 2000 years [2].

The Peninsula served as the battleground for Chinese and Japanese. Chinese leaders referred Korea as a "hammer ready to strike at the head of China" (Herbert Adams Gibbons, 192) while standing at the very gateway between Japan and the rest of Asia, Japanese called Korea a "dagger pointed at the heart of Japan" [1]. China claimed the Korean Kingdom as a tributary state of successive Chinese dynasties especially starting from the 8th century while Japanese went far to make the peninsula part of its Empire [3-5].

Moreover, in the middle of the 19th century, Russia, the United States, Great Britain, and France came as a strong player in the Korean Peninsula. Russia in particular inspired in Korea for the fulfillment of the desire for an ice-free, all-year-round port [6].

France, following the killings of missionaries in Korea in 1866 , proposed to march to the conquest of Korea and established a protectorate over the Peninsula [7]. They fought with Koreans, captured and burned the town of Kanghoa, and finally, strongly pushed back, and forced to leave the peninsula [5]. Similarly, Great Britain was already contesting for hegemony over Northeast Asia among China, Russia, and Japan. In 1832, the British East India Company sent a religious and commercial expedition to Korea, however, failed to attain results of any importance [8].

The United States of America was not indifference. It actively engaged in the politics of the Peninsula. According to Department of Stats, U.S., the involvement of the United States of America in the Korean Peninsula traced back to the Edmund Robert's report [7]. On May 13, 1834, after his return from the Orient, Edmund Robert reported to the United States Secretary of State that opening Japan has 
an advantage of trading with Korea. Starting from this time onward United States of America pig-headedly engaged in the Korean Peninsula until she got an official permission of the Korean government with a formal Peace, Amity, Commerce, and Navigation treaty.

The United States went far to wage war over Korea, in which Daesook Suh eulogized as one of the bloodiest battles that Koreans have fought to defend their country, to get its signature [9]. It made the agenda of "opening Korea" the centerpiece of its foreign policy of the Far East, especially in the 1860s, 70s. Tyler Dennett described American efforts to open Korea as "by far the most political action undertaken in Asia" [4]. Charles Oscar Paullin in his article "the Opening of Korea by Commodore Shufeldt" further stated that the most important work of the American Navy in the Far East during the 19th Century was concerned with the Opening of Korea, "the hermit nation", especially the 1871 Korean war was so significant in KoreanAmerican diplomacy history since it was the first time that American ground forces actually seized, held, and raised the American flag over territory in Asia $[5,10]$.

However, the 1950-53 Korean War overshadowed the earlier American-Korean relations history. As Gordon H. Chang explicitly stated the 1950-53 war dominated both America and Korean popular and scholarly understanding of Modern Korean History, obscured what came before as well [10]. Worse, most people failed to have an interest in the history of Korean-American relations before a formal treaty was signed in 1882 .

Therefore, this paper sought at assessing the persistent dream of U.S. to made Korean gates open for foreigners. The paper further tried to explain major incidents happened during the process of opening Korea and the repelling factors for a treaty on the side of U.S. The paper used forerunner literatures such as The Opening of Korea by Commodore Shufeldt, Seward's True Folly: American Diplomacy and Strategy During "Our Little War with the Heathens," Korea, 1871 by Ian Murray, United States Policy Regarding Korea by Department of State, U.S, America in Eastern Asia: a Critical Study of the Policy of the United States with reference to Gina, Japan and Korea in the 19th Century by Tayler Dennett, Whose "Barbarism"? Whose "Treachery"? Race and Civilization in the Unknown United States-Korean War of 1871 by Gordon H. Chang, The Low-Rodgers Expedition: A Study in the Foundation of U.S. Policy in Korea by Doulas Edward George, to synthesize of understanding and knowledge [4,7,10-12].

\section{The Involvement of U.S. in the Korean Peninsula}

The long journey of Korean-American relationship is neither thorn less nor full of success rather it was undergone within pains and daunting failures. Historically, the first United States representative to Korea arrived in Seoul in 1883. However, the initiation of U.S. to the Korean Peninsula dated back to 1834 Edmund Robert's report $[8,13]$.

\section{Edmund Robert's voyage}

On 1827, Edmund Robert, a forty-seven-year-old merchant, designate to undertake a voyage to the Indian Ocean as a supercargo of the big "Mary Ann". He successfully negotiated with Siam, Muscat in the Indian Ocean [14]. Again in 1832, Andrew Jackson sent Edmund Roberts on a voyage to negotiate commercial agreements with Japan, but he failed to realize the negotiation [11]. the Secretary of State, John Forsyth, regarding the importance of opening Japan. In his report, Edmund Robert underlined that one of the advantages of opening Japan was the possibility to trade with Korea [7]. Thus, starting from this time onward the country "Korea" came to the play of United States trade and commercial interest [13].

\section{The way to negotiation}

Since American clipper ship, the Empress of China, arrived in the Chinese port of Canton (Guangzhou) in 1784, Americans had demonstrated a growing interest of trade in the East Asia [13]. In the Asian market, it stiffly computes with other Western powers like Great Britain, and in 1839, the United States became the most knowledgeable power especially in the Pacific basin [11].

The United States commercial interest in the Far East ignited from time to time, and the potential for trade in Korea was thought to be sufficient to make commerce worthwhile. As a result, the United States felt it necessary to make some formal arrangements for the safe return of shipwrecked mariners from Korea waters [15]. However, as far as Korea concerned, during the early and the mid-19th Century, Western intrusion into Korea was "unwelcome and unwanted" [16]. Moreover, there was a huge political, economic and social differences between Korea and America [13]. Hence, the process of reaching commerce negotiation with Korea took almost half a century, and the way to negotiation was rough-and-tumble.

The First attempt to open Korea was 10 years after the report of Edmund Robert. On February 15, 1845, the Congressman Zadoc Pratt, Chairman of U.S. House Committee on Naval Affairs, introduced a resolution for a mission to Japan and Korea in order to open them to trade. Unfortunately, the resolution filled to pass $[7,17]$.

The second attempt was in the post-civil war period. In 1855 American maritime activity reached its highest pick, the golden age, in which American shipping totaled 5,212,000 tons, and regarding East Asia, American Exports to China, which had totaled only about $\$ 2$ million in the $1840 \mathrm{~s}$, rose to nearly $\$ 9$ million in the 1860 s [11]. The increasing significance of Pacific trade spurred the American Government into action on the Far Eastern front and the United States again renewed its efforts to open Korea to America trade. She used the Incident of General Sherman to march deep into the Korea water [18].

General Sherman, named after the famous American Civil War General, was an American centerboard trading schooner of Eight tons, with two large masts and a smaller sail on the foremost. For protection, the ship had two 12-pounder guns mounted broadside. General Sherman was owned by an American, W.B. Preston, but had been hired by a British firm, Messrs. Meadows and Company, to transport commercial freight and arms [11-13].

On August 1866, General Sherman sailed from Chefoo, China, a route to Korea for the purported purpose of conducting trade [19]. However, the real purpose of the expedition was controversial, since some scholars said the motives behind the expedition were involving the looting of royal tombs in the vicinity of P'yongyang [1]. The crew sailed into a rain-swollen Taedong River and move towards the city of Pyongyang [19]. The crew consisted of Portuguese, Chinese, Malay, and Captain Page who was American, and the Manager of commodities, George Hogarth, and the translator, Robert Jermain Thomas, were both British $[5,20]$. But the actual number of the crew was still controversial, especially the number of Chinese and Malay crew members were not accurately recorded. 
While anchoring the vessel, the Yi government issued orders to General Sherman to depart from Korea waters, and threatening to destroy the vessel and execute its crewmen but General Sherman ignored the warning of local officials rather pushed to the opposite side of Yang-jack Island which was not far from the city of Pyongyang [12,21]. Worse, on August 27, the expedition kidnapped Yi Hyonik, who was Pak Kyu-su's (Governor of P'yongyang Province) military aide, and four days later, cannon fire from General Sherman to Korean soldiers and civilians. The sum of these offensive actions roused Pak for retaliation [11].

Consequently, a clash broke out, the Korean sent fire rafts towards the schooner, but Sherman's superiority in weapons easily repelled, killing seven and wounding five Koreans. On the ongoing class, the receding waters of the Taedong left the general Sherman vessel stuck in the mud, and all the crew members calmed down hopelessly. Then, on September 5, 1866, enraged Koreans attacked and burned the vessel at the banks of Taedong River [13,20,21]. Finally, six survivors tried to surrender but an angry mob beat them to death and executed the rest [1]. However, still, there was no scholastic agreement on the number of survivors. Some sources pointed out that there were no General Sherman survivors, while others decreased the number of survivors $[10,20]$.

One fact to know here is, the sail of General Sherman was not sponsored by the U.S. government, nor did the U.S. government have foreknowledge of his sailing to Korea. It was purely a private entrepreneur undertaking [12]. However, in late January 1867, the incident of General Sherman reached the ears of United States Secretary William H. Seward who was assumed the role of Secretary of State under President Abraham Lincoln March 5, 1861. While hearing the incident, he became outraged [12].

William H. Seward, U.S. Secretary of State from March 5, 1861, to March 4. 1869, considered the Far East important from the very beginning of his tenure, used the Sherman incident as an opportunity to open Korea [22]. He favored a might driven type of diplomacy. According to Tyler Dennett, "Seward, more than any Secretary of State before or since his day, was favorably disposed toward a "gunboat diplomacy" $[4,11]$. Therefore, he intensively pressurized the United State Government to take action and "Opening Korea" [12]. Accordingly, on June 27, 1868, the Secretary of State mandated Secretary Seward so as to proceed to Korea to negotiate a commercial treaty. However, during this time conditions were unfavorable to the success of the mission, and no such expedition materialized, primarily because the French had already responded unilaterally on October 16, 1866 , with a heavy attack on Ganghwa Island, and they considered that was sufficient punishment $[7,12]$.

Notwithstanding the daunting failure of Opening Korea, the United States didn't want to give up; thus, two years later for third time, a further effort to open Korea was initiated and on April 1870, Secretary of State Hamilton Fish instructed U.S. Minister to China, Frederick F. Low, to negotiate with Korea [1].

In 1871 Frederick F. Low, a wealthy businessman, former U.S. Congressman, and former governor of California, having collected all the accessible information relevant to navigation to Korea, started the long voyage from Shanghai to Nagasaki, from Nagasaki to Korea $[10,20,21]$. He was accompanied by rear-admiral Rodger, who was a commander in chief of America navy of the Asiatic squadron and son of a celebrated American commodore, assembled their expeditionary forces; five steamships (the Colorado, Monocacy, Palos, Alaska, and the
Benicia), carrying eighty-five guns, 1,230 sailors and marines $[5,20]$.They arrived at Chemulpo (present-day Inchon) on the west coast near Seoul in May 1871 [20]. Gordon H. Chang described the expedition force as it was the largest Western military force to enter into the Korean territory until the 19th century [10].

As soon as arrived at Chemulpo, Frederick F. Low contacted Korean emissaries for negotiating but they said, they needed government approval. While waited, in June Rodgers sent a survey team to explore Kanghwa Island [5]. While the survey team went deep into the Island, Korean batteries delivered cannon shots at the team, but there were neither killed nor seriously injured [20]. In return, Low led a punitive operation against the Koreans. U.S. forces seized and burned forts and killed more than 240 Koreans including their commander while suffering three deaths and 10 casualties. Some scholars called it the first Korean War [1].

The U.S. flotilla arrived at Korea's Taeyong Islands on May 19, and the arrival of the American fleet immediately attracted the attention of local Koreans, most of them abandoned villages and took everything they could carry $[10,20]$. Late on May 30 , the fleet anchored at Chagyak, near the mouth of the Yomha River, which led directly to the Han River, and it was one of the most strategically sensitive in Korea, with Seoul, the capital, only fifty miles up the Han from the coast. At Chagyak, Low established the fleet's operations base [10].

On May 31, King of Korea sent three officials of the 3rd and 5th ranks to meet with Minister Low [12,23]. However, Low replied as a business would only be made known to a high official and he declined to see them $[1,12,21]$. Instead, he sent Mr. Drew, Mr. Cowles, and Lt Cmdr Wheeler. Mr. Drew, acting as Low's deputy, informed the Koreans that the Americans wanted to meet Korean official of rank commensurate with that of the U.S. Minister [10,12]. But the officials persistently pressed Mr. Drew to see Minister Low and Admiral Rodgers, even by stating they had seen the letter Low sent to the King from Peking, Drew rigidly told them that discussions wait for a higher official. Then, the Korean officials departed leaving the Americans with an uneasy feeling [12].

While waiting for higher official contact, at Low's direction, Rodger sent a surveying team towards Kanghwa which contradicted with the Korean law which forbids foreign vessels to progress beyond certain "water-gates" [20,21]. On May 31, the survey team reached Ganghwa Island in the estuary of the Han River [1]. In return, Koreans set beacon-fires on every hilltop visible from the anchorage. Koreans made ready themselves for the inevitable war. What was worse, the next day, June 1st, Admiral Rodgers organized another survey expedition to proceed beyond Kang-wha. This new group of survey vessels consisted of the Monocacy, under the command of Commander McCrea, the Palos, under the command of Lieutenant Commander Rockwell, and the four previous steam launches commanded by Lieutenant Commander Chester, Lieutenants Meade and Totten, and Master Schroeder. The officer in charge of the entire survey expedition was again Captain Blake who commanded from the Palos [12].

When the expedition surveying coast and river channels, the Koreans agitated. However, unknown to the Americans, the Korean king had ordered all officials along the coastal areas to avoid provoking any conflict with Americans [10]. As a result, the survey went about its task peaceably, and eventually, approached the lower end of Kanghwa Island, to Sondolmok, there a long line of earthworks and fluttering yellow flags came into view, as well as large numbers of white-clad Korean troops $[10,20,21]$. Upon rounding a sharp bend on the river 
eighty masked Korean batteries on both sides of the river opened fire on the American vessels [13,20]. Immediately, the Monocacy and Palos returned fire, but suddenly, the Americans found themselves approaching a high bluff on the river which was some type of citadel fortification. They counter maneuvering before reaching the citadel [12].

"As we came up abreast, a single shot, apparently from a musket or pistol, was fired from near the standard, and instantly, from the fort and masked batteries along the face of the hill, they opened a heavy fire upon the ships and boats, which was promptly returned from all the vessels, and which soon drove them from the guns, they retreating to the ravines" [1].

The whole engagement only lasted about 10-15 minutes, no Americans were killed, and the only two slightly wounded [21]. In Korean side, "not a few" were killed and "many tens" wounded [12].

After the skirmish, the whole survey expedition returned safely by on the same day, and Korean local authorities immediately dispatched a message to the King, reporting that two sailing vessels with two masts have forced their way into Sun-Shih passage, which was the most important pass leading up into the river, we have increased the guard, and done everything to make it secure [12]. On the other hand, Captain Blake returned and informed Admiral Rodgers and Minister Low what had happened, the two men were totally enraged. Admiral Rodgers wanted immediate retribution. So did Minister Low [1].

Low opted to present the Koreans with a ten-day ultimatum. Low decided that if the Koreans did not apologize for their aggression at Sondol-mok within 10 days, they would be subjected to American retaliation $[1,20]$. On the other hand, Koreans said, the advance of the American surveying team provoked the engagement and so that they will not ask for apologizing [13]. They argued that once the vessels violated an important passageway, how could the officers, appointed to guard the frontier, whose duty is to take measures of defense, calmly let it go by as of no consequence [10].

Low suspended the 10 days ultimatum, and wait for an opportunity to attack [21]. During this time, a curious system of communication developed, each night, Koreans affixed messages to a pole erected in the mud flats near where the American fleet was anchored, and the Americans would collect these messages each morning [1]. In addition, on June 4, Pak Kyusu directly sent a letter to the American fleet, informing them that Korea simply could not understand their intentions, and imploring the Americans to understand Korean suspicion [1]. However, none of the messages satisfied Low's demands.

Over the next few days, while the Koreans on Kangwha Island busily prepared their fortifications, the Americans continually observed Korean troop movements and reconnoitered the proposed attack area. The Koreans were continuously drilling their troops, signaling each other from the hilltops at night, and they even made a makeshift attempt to cover the road to Seoul. Likewise, American preparations were also progressing at a rapid pace. Admiral Rodgers devised a solid plan in which the battalions of the different ships were combined into a formidable combat division under the command of Captain H.C. Blake [12].

Now nothing was left undone, only waging war. But, on June 7 th, in a last-ditch attempt to stave off the attack, the Koreans sent one last letter and presents to the Americans on board, the gifts consisted of some poultry and livestock (three bullocks, 50 chickens, and 1,000 eggs) to succor, or possibly to appease the Americans, but Americans stick to their stand $[1,10]$. Accordingly, on June 9th, Admiral Rodger's attacking plan was set, the attacking force was to consist of the corvettes Monocacy and Palos, the four-armed steam-launches, and 20 armed launches and boats to convey the men. The landing force of 651 men was to be conveyed to the combat area by the corvettes, then ferried to land by the boats and armed launches. The landing force was arranged into ten companies of infantry and seven pieces of artillery. Another 105 men would be standing by supporting them on the vessels involved [12].

Saturday, June 10th, the day set for the landing [23]. Early that morning the boats were lowered from the ships and the battalion equipped. The late morning departure was designed [12]. Overall command of the expedition was under Commander Homer C. Blake of the U.S.S. Alaska, who was to direct the expedition from the Palos. His adjutant-general was Lieutenant Commander W. Scott Schley, who decades later would become a leading figure in the Spanish-American War. At his own request, ground forces were placed under Commander Lewis A. Kimberly of the Benicia. The landing force was led by Captain McLane Tilton who, with four junior officers, led the 100-man Marine detachment ashore. From the ranks of every ship in the squadron Lieutenant Commander Silas Casey had assembled a bluejacket battalion of 542 sailors. An artillery detachment with seven twelvepound guns completed the force, and was sent ashore under the command of Silas Casey [21].

Advance up the river was led by the Monocacy, which was flanked by a steam-launch on each bow. The Palos followed with its caravan in tow [12]. The battalion approached the first Korean fort. Monocacy rounded a point and opened fire on the lower forts. The initial bombardment lasted for almost two hours. Most of the Korean garrison quickly fled, Americans continue to advance and quickly took possession of this lower fort. Monocacy continued upstream to bombard the middle fort, this time the Koreans responded with their artillery. But their aim was not accurate, and damage to the American vessels was minimal. Monocacy continued pounding till nightfall [12].

On Sunday, June 11, the second day of the incursion, the battalion reached the second fort, which they fondly named Fort Monocacy. The Americans also set fire to all the fort's buildings that they judged might be used for military purposes. Regrettably, that lire reread to and destroyed an entire village north of the fort. Their jab finished at the middle fort, Kimberly's men headed straight for the main fort, Fort du Cande. The Americans nicknamed it "the Citadel," and it was by far more formidable than the forts already taken [12]. It was garrisoned by the elite of the Korean army, the "Tiger Hunters," men who were all sworn to fight to the death. Commander McCrea on the Monocacy opened a merciless cannonade that lasted for over an hour [21].

McLane Tilton said the Koreans "fought like tigers", and Adm. John Rodgers described the fighting to his wife: "the Koreans fought desperately-if no weapon was at hand they picked up stones and threw them-some who were pinioned to the earth with bayonets threw dust on their conquerors. The record from the Korean side also tells of terrible fighting and slaughter. Field reports describe the "fierce fighting of the Western enemy" and the inability of the Korean forces to stop their advance [10]. But American howitzers made it impossible for Korean to mount an effective attack [12]. Realizing defeat was imminent; some of the Koreans, like the Korean general, leaped to their deaths or pierced themselves upon their own swords to the death [21]. Hopelessly, the Koreans withdrew and left a clear field [10]. 
The battle completely finished, the set across Kanghwa Island, little remained of the Kwangsung Fortress but piles of broken rubble and bloody Korean bodies. The Americans counted 243 corpses in and around the fortress and took captive 20 Koreans who had been severely wounded [21]. However, the number of deaths differed from different sources; Gordon H. Chang and Gordon H. Chang stated that around 250 Koreans had been killed in the combat, while Woong Joe Kang wrote that Korean record listed a 53 killed and 24 wounded casualties [20].

The Americans had also captured fifty Korean flags, including the huge yellow banner of the Koreans' commanding general, and five forts had been taken and everything in them destroyed [23]. American losses stood at just three killed and nine wounded. The dead were Lieutenant Hugh McKee, the first man into the Citadel (the Americans later renamed the Korean fort Fort McKee), Seth Allen, a Navy landsman from the Colorado, and Dennis Hamahan, a marine private from the Benicia. Allen and Hanahan were buried somewhere on Eoisee Island, and McKee' s body was embalmed and sent home [12].

The morning of June 12, the incursionary force left the Citadel with a profound sense of accomplishment and pride. When the Koreans reoccupied the forts after the American withdrawal, they found horrible ruin, with mangled bodies everywhere. Every Korean gun in the forts had been dismounted, every storehouse destroyed, and every magazine blew up. Koreans stated:

"Look at it now, one can know this much certain; under outward professions of friendship, you cherish false and deceitful design. To come to your landing, and thoroughly displaying your forte of committing public buildings to the flame, burning cottages, stealing property and sweeping up everything to the veriest trifle. these are the action of thieves and spies" [13].

The court decided to continue to have nothing to do with the Americans. Convinced that the events confirmed Korean righteousness and moral purity, the court reaffirmed its seclusion policy to protect its own civilization and the Korean Government also celebrated the American withdrawal as a great victory and a vindication of their time-honored policy of seclusion $[1,11,17]$.

After the withdrawal of U.S., Japan started pressuring Korea and on February 27, 1876, they signed the treaty of Kanghwa, the treaty opened up three Korean ports including Pusan to Japan trades [1]. Then, the Americans were once again showing an interest in negotiating a commercial treaty with Korea, and in 1880 Commodore Robert Shufeldt went to Japanese officials if Japan could help to arrange talks between U.S. and Korea [13]. This led to another phase of negotiation through the good office of Japan.

In spite of the continuous failure, United States interest in Korea didn't abate. In April 1878, Senator A. A. Sargent introduced a joint resolution authorizing the President to appoint a commission to negotiate a treaty with Korea with the aid of the friendly office of Japan. This resolution; however, never adopted. Then, later on, October 29, 1878, Navy Secretary Richard W. Thompson authorized Admiral Robert W. Shufeldt to open Korea for America [1]. In April and May 1880 Shufeldt attempts with the assistance of the good office of Japan to enter into negotiations with the Korean authorities. At first, Shufeldt attempted to exploit the newly forged Japan-Korean intimacy, but Japan suspected ulterior motives and impeded his efforts, and all attempts were unsuccessful. Shufeldt then, traveled to China to meet $\mathrm{Li}$ Hongzhang, a key Chinese official who was in charge of China's Korean Policy. Li concluded that if he encourages the Koreans to enter into talks with Shufeldt $[1,13,23]$. Then, the good office of China used as an instrument of negotiation with Korea.

In the summer of 1880 Hung-chang, the Chinese Viceroy at Tientsin assured Shufeldt that he will use his good offices to induce the Korean government to enter into the treaty with U.S. [24]. Thus, Shufeldt was back in China in the summer of 1881 , on a special duty at the American Legation in Peking, but with headquarters in Tientsin. Li offered to use his authority to persuade Korea to negotiate, evidently hoping to exploit the negotiations to offset Japan's recognition of Korean independence. Li enlisted Chinese officials to transport the treaty to Korea on board a Chinese ship, despite the fact that Shufeldt refused to insert a clause recognizing Korean subservience to China, Shin Chen and Chin Hong-Chi of the Korean Royal Cabinet signed the Shufeldt Treaty of Peace, Amity, Commerce and Navigation on behalf of King Gojong on May 22, 1882 [1,25,26]. Japanese and American success in Korea inspired a great contest for Korea, with Great Britain and Germany securing treaties with the Hermit Kingdom in 1883, followed by Italy in 1884 and France in 1886 [24].

Then, the treaty as drawn up in Tientsin, was signed in Korea by Korean Commissioners and Commodore Shufeldt on May 22, 1882, U.S. became the first Western power to sign a treaty with Korea and the U.S. Senate consented to the treaty on January 9, 1883; then, ratification was exchanged in Seoul on May 19, 1883 [24,25]. The treaty was proclaimed by the president on June 4,1883 .

\section{The Content of the Treaty}

The peace, amity, commerce, and navigation treaty between the United States of America and the Kingdom of Chosen (Kora) signed at Yin-Chun on May 22, 1882, and ratification by the President of the United States of America, with an understanding, took place on February 13, 1883, whereas Ratification by Korean took place on May 18,1883 . The ratification was exchanged at Seoul on May 19, 1883, and entered into force on May 19, 1883. On June 4, 1883, the president of the United States made a proclamation, and H. Foote was appointed Minister to Korea [1,12,15].

The treaty consisted of a total of XIV (14) Articles and U.S. understandings on article VI. This treaty was in many respects a typical 19th-century treaty. Article one of the treaty discussed on the friendship relation between Korea and America as an independent nation including to stand together against unjust or oppressive dealings. From the beginning, the treaty considered Korea as an independent nation. During the talk between Shufeldt and Li Hong Chang in Tianjin, the later had originally insisted that the treaty contain an article clearly stating that Korea was a tributary state of China. However, Shufeldt rejected the proposition and declared that the United State did not offer any diplomatic recognition to any nation that might be legally bounded by another $[13,26]$. Accordingly, in instructions to the first American Minister in Korea, the Secretary of State wrote:

"As far as we are concerned, Korea is an independent sovereign power with all the attendant rights, privilege, duties, and responsibilities; in her relations with China, we have no desire to interfere unless action should be taken prejudicial to the rights of U.S [7].

In addition, as per this article, the United States agreed to defend Korea to remain an independent nation, even though Americans failed 
to fulfill while Japan controlled Korea on August 29, 1910, which led to an official termination of the treaty.

Article two stipulated the necessity of diplomatic representatives to reside at the court of the other and consular representatives at the port of each other. As a result, in the Spring of 1883 Lucius H. Foote arrived in Seoul to begin serving as America's first Minister in Korea and in the Fall of 1883 a large group of Korean diplomats and officials went to the U.S., met American government officials and tour the urban and industrial development of U.S. at the time [25].

The third article was about the United States vessels in Korea. It stated that in a situation when the United States wanted a fuel, could enter any port or harbor. However, if the vessel carried on a clandestine trade at a port not opened for foreign commerce, its cargo would be seized and confiscated.

The fourth article summarized on the freedom and security of citizens of U.S. in Korea. It stated that the Korean Government will fully protect them from any insult and injuries and cherished fullfledged freedom to attend their own affairs. This article answered one of the dreams of the U.S shipwrecked and promised that there will no more General Sherman Incident.

The fifth article was about their merchant and merchant-vessels went and came to Korea and the U.S. It concluded that when Korean merchants and merchants-vessels went to the U.S. for the purpose of traffic, they should pay duties and tonnage-dues and all fees as per the customs regulation but not more than levied upon citizens. On the other hand, when U.S. merchants and merchants-vessels went to Korea for the purpose of traffic, shall pay as per the merchandise imported and exported as fixed by the authorities of Korea.

The sixth article stated about the people who want to reside, rent premises, purchase land, to construct residences or warehouse in both countries. The article explained that Korean people were allowed to do so and citizens of U.S. as well in opened ports. This article paved the way for assimilation and integration of Americans in Korea, and Korean in America as well vis-a-vis.

Article seven detailed the prohibition of import and export, trafficking of Opium to both countries, and Article eight explained that whenever there was the scarcity of food, the king of Chosen may decree temporarily prohibit the export of food and food-related stuff.

Article nine conveyed that purchase of firearms allowed only to officials of the United State only under written permit from the authorities of Chosen, and the 10th Article of the treaty indicated that either nationality has the right to employ natives for all kinds of lawful work. Article eleven allowed either nationality to study in either of the countries.

The rest four articles $(11,12,13,14)$ predominantly dealt on the exchange of students, the language used for the treaty (the Medium of language was either Chinese or English), the possibility of further negotiation after 5 years, and the ultimate power reside on both contracting parties respectively.

The treaty was finally, terminated on August 29, 1910, when Korea failed under part of the administration of the Japan Empire.

\section{Why Koreans Change Their Mind?}

Leadership change in Korea refreshed the situation. When Kojong reached adulthood and assumed real power in 1873, the isolation of his
"Hermit Kingdom" and anti-foreign country attitude was relaxed, showed a certain tendency of friendship with especially America [25]. The reason for the change of interest can be summed up into two dimensions.

\section{Personal understanding}

Kojong persistently sought an American aid in trying to solve Korean problems especially to maintain his people autonomy and political identity amid the harsh environment of both Western and Asian Imperialists. Kojong expected too much from the United States in trying to modernize and free his Kingdom first from the domination of China, then Japan. Therefore, Kojong became pragmatist and proAmerican. He convinced that the United States was a powerful industrialist and anti-imperialist power, a moral state founded upon Christianity, which usually supported weaker states against strong oppressors [25].

\section{Geographical understanding}

Kojong and many other Koreans believed that the United States, thousands of miles away from the Pacific, would have no evil or ulterior motives. If the United States had been close by, the Koreans undoubtedly have had substantial misgivings about it suggested by Yur-Bok Lee and Wayne Patterson [25].

\section{Fundamentals of U.S. for Treaty}

Throughout the middle decades of the 19th century, U.S. had had both implicit and explicit reasons to sign a treaty with Korea. The most prevailing fundamentals of the treaty can be categorized into three:

\section{The opening of Korean ports to U.S. trade}

American interest in the Far East had been primarily of a commercial nature [27]. The potential for trade in Korea was also thought to be sufficient to make commerce worthwhile particularly since the United States merchants had realized a profit with China, and even more so with Japan, where the United States played a most important role in opening the country for trade [25]. Every plenipotentiary who crossed the Pacific to negotiate such as Caleb Cushing, Matthew C. Perry, Townshend Harris, George F. Seward, Frederick Low, and Robert W. Shufeldt, carried with him the same American principles, the opening of Asian commerce. The differences between these missions, therefore, were not ideological, it was only strategically [1].

\section{Legal protection for shipwrecked American sailors}

A continuation of opening trade, United States insisted on protection of United States ships and mariners as they sailed in Korean waters [18]. More important than potential trade, United States commercial interests felt it necessary to make some formal arrangements for the safe return of shipwrecked mariners in distress in Korea waters as they plied between China and Japan [16].

\section{Striving to earn most-favored-nation status}

According to the American Journal of International Law (1976), the idea of Most-Favored-Nation introduced in the 17th century. However, it was in the latter half of the 19th century the clause extensively used between the European powers and Asian countries. Article I of the 
Citation: Birru DT (2018) The Korean Peninsula and the Dream of the United States of America (1834-1882). Arts Social Sci J 9: 422. doi: $10.4172 / 2151-6200.1000422$

Page 7 of 8

General Agreements on Tariffs and Trade (GATT) 1994 defined the term Most-Favored-Nation as the reciprocal extension of any concessions, privileges, or immunities granted, or yet to be granted, by a country in a trade agreement (or in some other way) to one country which is, or would be, the "most favored" in this respect to all countries to which it accords Most-Favored-Nation treatment [28-30].

In the middle and late 19th century the U.S. used the Most-FavoredNation Policy for treatment of its trading partners by means of a bilateral compact (e.g., a "friendship, commerce, and navigation" or similar treaty, or an executive trade agreement) in which MostFavored-Nation status was accorded reciprocally [28,31-33]. U.S. trade officials used the Most-Favored-Nation principle to get special privileges and offered special concessions for raw materials and agricultural goods for the U.S. market or in the U.S. market reciprocally. They sought either unilateral Most-Favored-Nation treatment or one-sided agreements that assured the United States of Most-Favored-Nation treatment (Encyclopedia of the New American Nation, 2018). As a result, U.S. directly or indirectly influenced countries to enter into trade treaties which provided America with Most-Favored-Nation access to their market. What happened in Korea was no different. The U.S. forced Korea, went far to wage war, to sign a commercial agreement and then, got access to the Korean market.

\section{Conclusion}

In the middle and late of 19th century, the United States of America devoted to the execution of its own national interest in the Korean Peninsula, "opening Korea" for the American market. On the Contrary, the "Hermit Kingdom" followed a policy of isolation, protecting the Kingdom from the intrudes of especially Westerners. The existence of these contradicted poles of interests between these two countries made the process of reaching an agreement, in the form of a formal treaty, so tiresome.

Starting from the time when Americans heard about Korea, 1834 Edmund Roberts report, they tried to open Korea. Their first attempt was in 1845 when a resolution was proposed to open Korea and Japan, accordingly Japan opened in 1854, Korea remained closed. Thus, America exerts their full effort to make Korea opened. The most visible attempt was the 1871 Low-Rodger expedition deep down to Korean waters. This expedition was to influence Korea to brought into a negotiation, but Koreans refused. Despite the refusal of Korea, Low declared a war and tried to bring Korean into negotiation. But the result was a distraction of five forts and killings of more than 240 Koreans, 3 American, and other resource damages, still Koreans preferred their isolation. Force unable to bring Korea to the table, and this showed the value of force in diplomacy was insignificant, as far as the "Hermit Kingdom" concerned.

However, the transition of power in Korea took placed, Kojong reached adulthood and assumed real power in 1873, and the isolation of his "Hermit Kingdom" and anti-foreign country attitude was relaxed, showed a certain tendency of friendship with especially America. Therefore, through the good office of China, the peace, amity, commerce, and navigation treaty between the United States of America and the Kingdom of Chosen (Kora) signed at Yin-Chun on May 22, 1882.

The ratification by the President of the United States of America, with an understanding, took place on February 13, 1883, whereas Ratification by Korean took place on May 18, 1883. The ratification was exchanged at Seoul on May 19, 1883, and entered into force on
May 19, 1883. On June 4, 1883, the president of the United States made a proclamation, and $\mathrm{H}$. Foote was appointed Minister to Korea.

\section{References}

1. James IM (1948) Crises in a Divide Korea: a Chronology and Reference Guide.

2. Yu Nam Kim (2009) The Geopolitics of the two Koreans and the United States: Seen through the North Korean Nuclear Issue. A paper prepared for delivery at the American Political Science Canada.

3. Colonel Russell Maddalena (2014) Why does the People's Republic of China continue to Support the Democratic Republic of Korea? Australia Defense College, Center for Defense and Strategic Studies.

4. Tayler Dennett (1922) America in Eastern Asia: a Critical Study of the Policy of the United States with reference to Gina, Japan, and Korea in the 19th Century The Macmillan Company, United States of America.

5. Charles OP (1910) The Opening of Korea by Commodore Shufeldt. Political Science Quarterly 25: 470-499.

6. Edmund J Zvetina (1952) Imperial Russian Interest and Intervention in Korea.

7. Department of State, US (1987) United States Policy Regarding Korea Institute of Asian Culture Studies, Hallam University Press.

8. George M, Mccune, John AH (1951) Korean American Relations 1883-1886. Documents Pertaining to the Far Eastern Diplomacy of the United States Berkeley and Los Angeles, University of California Press Vol-11.

9. Sook Suh D (1984) The Centennial: A Brief History in Korea and the United States: A Century of Operation Honolulu.

10. Chang GH (2003) Whose Barbarism? Whose Treachery? Race and Civilization in the Unknown United States-Korean War of 1871. The Journal of American History 89: 1331-1365.

11. Murray I (2011) Seward's True Folly: American Diplomacy and Strategy During Our Little War with the Heathens, Korea, 1871 Penn Libraries, Vol-18.

12. Doulas EG (1988) The Low-Rodgers Expedition: A Study in the Foundation of US Policy in Korea Master Thesis, Naval Postgraduate School, Monterey, California.

13. Gurtov M, Larson JF, Robert RS (1996) Korea's Amazing Century; From Kings to Satellites Korean Fulbright Foundation and Korean-American Education Commission, Seoul, South Korea.

14. Cole AB (1941) Plans of Edmund Roberts for Negotiations in Nippon Monumenta Nipponica, 4: 497-513.

15. Gary D Walter (1969) The Korean Special Mission to the United States of America in 1883. Journal of Korean Studies 11: 89-142.

16. Donard GS (2005) Intrepid Americans: Bold Koreans-Early Korean Trade, Concessions, and Entrepreneurship Universe, Inc, New York Lincoln Shanghai.

17. Frederick Nelson M (1945) Korea and the Old Order in Eastern Asia Louisiana State University Press.

18. James B Palais (1991) Politics and Policy in Traditional Korea The Council on East Asian Studies, Harvard University.

19. Kyung MH (2017) The History of Korea an Episodic Narrative 2nd ed, Palgrave, UK.

20. Woong JK (2005) The Korean Struggle for International Identity in the Foreground of the Shufeldt Negotiation University Press of America, New York.

21. Sterner D (2002) Shinmiyangyo: The other Korean War .

22. Sexton J (2014) William H Seward in the World. Journal of the Civil War Era 4: 398-430.

23. Michael JM (1934) American diplomatic relations with Korea Graduate Student Theses, Dissertations Professional Papers.

24. Kleiner J (2001) Korea, a Century of Change World Scientific Publishing.

25. Lee YB, Patterson W (1999) Korean-American Relations, 1866-1997 State University of New York Press. 
Citation: Birru DT (2018) The Korean Peninsula and the Dream of the United States of America (1834-1882). Arts Social Sci J 9: 422. doi: 10.4172/2151-6200.1000422

Page 8 of 8

26. Walthall A Erby (2014) East Asia: A Cultural, Social, and Political History, 3rd ed, Suzanne Jeans Vol-2.

27. Gordon L (1957) Early American Relations with Formosa, 1849-1870 Wiley Online Library, 9: 262-289.

28. Vladimir N Pregelj (2005) Normal-Trade-Relations (Most-FavoredNation) Policy of the United States Congressional Research Service, The Library of Congress.

29. Murase S (1976) The Most-Favored-Nation Treatment in Japan's Treaty Practiced. During the Period 1854-1905 The American Journal of International Law,70: 273-295.
30. Herbert AG (1921) The New Map of Asia (1900-1919) 3rd print, New York, the Century CO.

31. Sun Kim C (1969) Sources of Cohesion and Fragmentation in the Silla Kingdom. Journal of Korean Studies 11: 41-72.

32. Wright Q (1940) The Present Status of Neutrality. The American Journal of International Law Vol-34.

33. Chris J Magoc, David Bernstein (2015) Imperialism and Expansionism in American History A Social, Political, and Cultural Encyclopedia and Document Collection. 